\title{
MODEL OF COMPETITIVE MANAGEMENT OF REGIONAL BUILDING PROJECTS
}

\author{
S.A. Barkalov, sbarkalov@nm.ru, \\ V.L. Poryadina, poryadina08@mail.ru \\ Voronezh State University of Architecture and Civil Engineering, Voronezh, \\ Russian Federation
}

This article describes the verbal model underlying the development of a software decision support competitive regional management of construction projects. Competitive management of projects is understood as the purposeful process beginning with the organisation and carrying out of competition in which result projects-applicants are ordered on the basis of certain criteria, then the winner (or winners) the applicant who has won first place (or, accordingly, some first places - depending on competition conditions), and proceeding appears up to project end.

Building projects are considered as complete symbolical systems, and management of them to represent a structural composition of four components: the subject of management, object of management; a project environment; algorithm of management of the project and criteria of quality of the project.

Based on the analysis and synthesis of project management experience in construction in this article was developed verbal model of competitive regional management of construction projects. The proposed model revealed and clarified the existing ideas about the structure of the organization and mechanisms for the implementation of regional projects and due to the evaluation criteria allowed more adequately articulate the problems solved in the stages of this type of competitive project management.

Keywords: region, building, project, competition, management, algorithm.

\section{Introduction}

Competitive management of projects is understood as the purposeful process beginning with the organisation and carrying out of competition in which result projects-applicants are ordered on the basis of certain criteria, then the winner (or winners) the applicant who has won first place (or, accordingly, some first places - depending on competition conditions), and proceeding appears up to project end. Thus, we recognise that competitive management it is not limited actually to competition, and extends on all life cycle of the project, since the first reference of the applicant in the administrative body responsible for the decision of building problems in given region, and finishing full realisation of the project.

Owing to an openness process of competitive management by building projects is always unique. An element of expert estimations and intuition here play an essential role. However however the experts who are carrying out this process were not talented, use of special technologies of the organisation and competitive management of design cycles is necessary. As a methodological basis of management of building projects we will be guided by the system model offered in $[1,2]$. According to this model we will consider building projects of the given type as complete symbolical systems, and management of them to represent a structural composition of four components: the subject of management; object of management; a project environment, algorithm of management of the project and criteria of quality of the project.

\section{The subject of management. As object of management. Project environment}

The subject of management are the active participants of the project co-operating at development and acceptance of administrative decisions in the course of its realisation. In our case them can be: a state structure which is carrying out formation of the program of development of region and organising competitions of projects; the investor; the customer; the general contractor, executors, co-authors, a command of management of the project (the project head, its assistants, managers of the project, etc.).

As object of management in our case actually building project at all stages and stages of a design cycle acts, since the moment of the first reference of the applicant of the project (local governments, the enterprise, the organisation, the private person) in a state structure and finishing its full realisation. 


\section{Управление в социально-экономических системах}

Project environment we will name the environment generating set of external and internal forces which promote or disturb to achievement of the purposes of the project. This dynamic environment renders certain influences (economic, social, legal, financial, organizational, information, etc.) on project components. Each of such influences can appear critical for the project and lead to its destruction. Therefore factors of an environment of the project should be analysed about their relevance and those from them which can make appreciable impact on designing process are allocated. It is possible to present typical factors of an environment of building projects in the form of a following three-layer train [3]:

$$
\left\{\begin{array}{l}
\langle\mathrm{P}, \mathrm{E}, \mathrm{OB}, \mathrm{Z} \& \mathrm{P}, \mathrm{P} \& \mathrm{E}\rangle ; \\
\langle\mathrm{RS}, \mathrm{RSP}, \mathrm{SOOS}, \mathrm{RK}, \mathrm{RR}, \mathrm{RU} \& \mathrm{~S}, \mathrm{SP}\rangle ; \\
\langle\mathrm{K}, \mathrm{ZL}, \mathrm{NF}\rangle,
\end{array}\right.
$$

Where $\mathrm{P}$ - a political situation; $\mathrm{E}$ - an economic situation; OB - public relations; $\mathrm{Z} \& \mathrm{P}$ - the law and the right; P\&E - the nature and region ecology; RS - a commodity market; RSP - the market of means of production; SOOS - environment protection services; RK - the capital market; RR - the market of building materials and completing products; RU\&S - the market of services and service; To - competitors; ZL - malefactors; NF - unforeseen factors.

\section{Algorithm of competitive management of building projects}

Principles are put in a basis of its working out staging, recurrence and iterative [6, 7]. Staging assumes that process of competitive management is realised not one act, and divided into a number of consecutive stages so that they covered all life cycle of the project. Recurrence assumes the organisation of managerial process in the form of set of the typical operations which performance yields the certain finished result allowing the competitive commission to accept intermediate or the final decision. Iterative provides numerous repetition of typical operations of management with gradual approach to some optimum (if it is possible and achievable) or to the compromise (to resolution of problems on the basis of reciprocal concessions).

The algorithm of competitive management developed on the basis of these principles is presented by regional building projects on Fig. 1. Figures in this drawing designate following operations:

1.1. Working out of the general concept of the project by the enterprise (organisation) by the applicant taking into account priority programs of development of the given region.

1.2. The first reference of initiators of the project in the body which is carrying out formation of the program.

1.3. The primary estimation of the project a state structure in which result the project or deviates as unsuitable basically, or on it is requested the full design documentation.

2.1. Working out by the enterprise (organisation) of the detailed design documentation.

2.2. Registration of the project and its giving in a state structure.

3.1. A full estimation of the project on set of criteria with which in the maximum degree should satisfy shown projects.

3.2. An estimation of conformity of the project to requirements of external investors.

3.3. Decision-making and on project acceptance/deviation, motivation of the made decision.

4.1. Formation of criteria on which basis selection of priority projects is made.

4.2. Ranging of projects.

4.3. The coordination of projects, formation of the program of their financing for planned year, its coordination with interested bodies, the statement and acceptance to execution by the manager of budgetary funds.

5.1. Revealing and the analysis of communications between projects.

5.2. Coordination of parametres of adjacent projects.

5.3. Signing of the contract on project realisation.

6.1. Payment of the confirmed means.

6.2. Monitoring of realisation of the project (project updating if necessary).

6.3. Coordination of design cycles.

7.1. An estimation of results of the project.

7.2. Representation to the manager of means of certificates and other accounting documents of the established sample. 


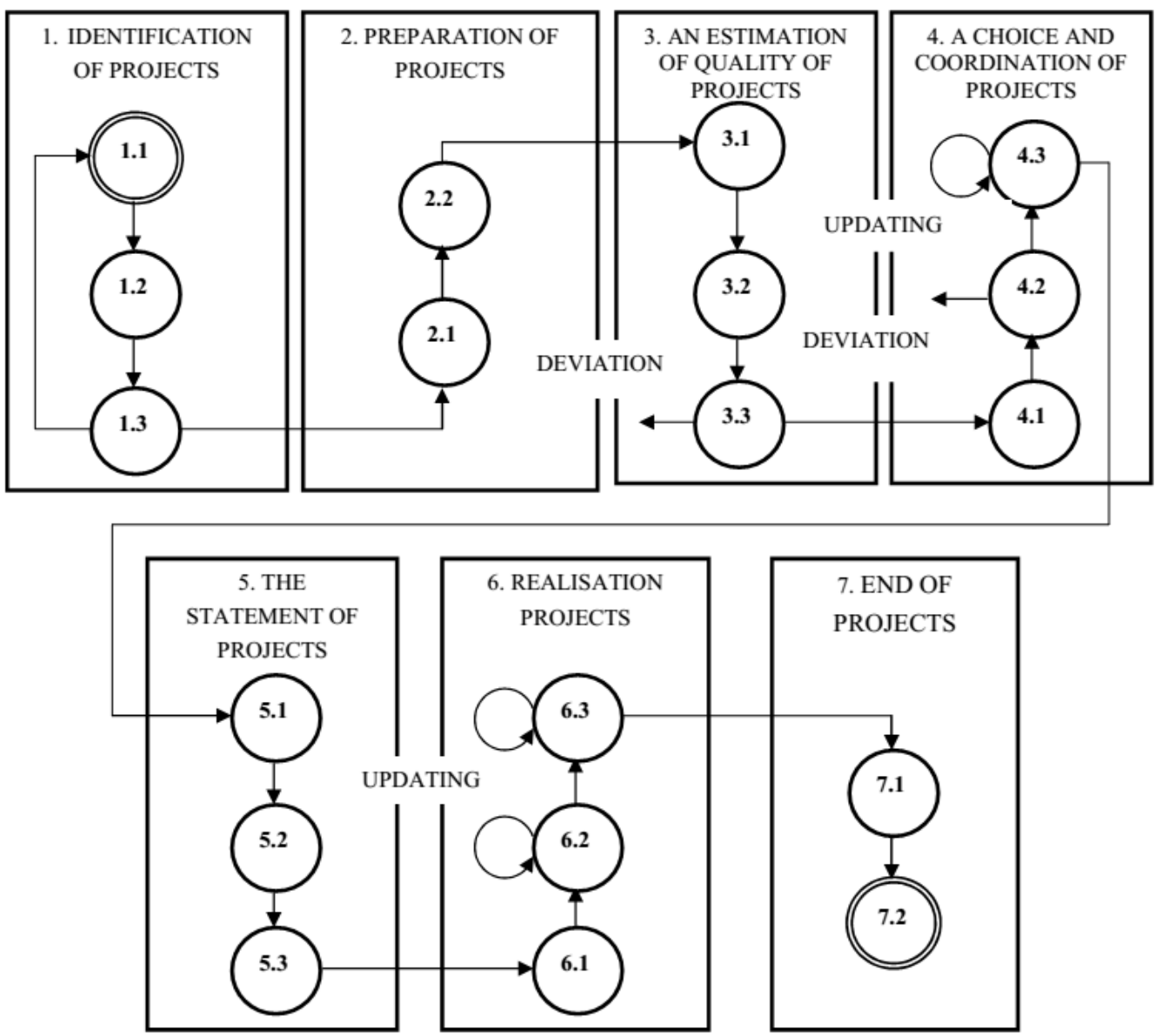

Fig. 1. Algorithm of competitive management of regional building projects [8]

3. Criteria of quality of management of the project.

The analysis and generalisation of experience management of projects in building and $[2,4]$ and mechanisms of functioning of organizational systems [5] shows expediency of an estimation of regional building projects by the criteria presented to Table 1 .

Criteria of quality of regional building projects

Table 1

\section{TARGET EFFICIENCY OF THE PROJECT}

1.1. Conformity of the project to priority programs of social and economic development of territory (area)

1.2. Degree of influence of realisation of the project on a historical infrastructure of territory (area)

1.3. Direct positive influence of the project on social inquiries of the population (level of the social importance of the project)

1.4. Presence of the adverse ecological and technogenic consequences connected with realisation of the project

1.5. Conformity of parametres of the project to building norms and rules

1.6. Quality of the technologies used at realisation of the project

1.7. Degree of influence of the project on development of a municipal and communication infrastructure of territory (area)

1.8. Degree of influence of the project on efficiency of realisation of adjacent projects (including not concerning to building)

\section{TECHNICAL VALIDITY OF THE PROJECT}

2.1. Degree of a readiness of the design documentation

2.2. Quality of the feasibility report on the project

2.3. Quality (validity level) project concepts 
Table 1 (end)
2.4. Level of a readiness of technology offered to use
2.5. Level of validity of expected target effect
2.6. Reception possibility additional effects from project realisation
3. ECONOMIC VALIDITY OF THE PROJECT

3.1. Comparability of possibilities of self-financing of the applicant to the size of its profit on project realisation

3.2. Possibility of self-financing of the project

3.3. Quality (validity level) project plan business

3.4. Realness of assumptions at drawing up project plan business

3.5. Level of study business of plans at co-authors of the project

\section{A PRACTICAL REALIZABILITY OF THE PROJECT}

4.1. Realness of the given budget for project realisation

4.2. Realness of the schedule of realisation of the project

4.3. Realness of prospective volumes of purchases of technics, the equipment, materials

4.4. A professional standard of a command of the project

4.5. Level of the social importance of the project

4.6. Realness of creation of cooperation of executors of the project

4.7. Degree of the coordination of the project with other building projects

Target efficiency of the project proves to be true, first of all, its conformity to priority programs of social and economic development of region where its realisation is supposed. Then degree of influence of the project on a historical infrastructure of territory (area), its direct positive influence of the project on social inquiries of the population (level of the social importance of the project) and possibility of the adverse ecological and technogenic consequences connected with realisation of the project is estimated. Further the project estimation on conformity to building norms and rules and as quality of used building technologies and degree of influence of the project on development of a municipal infrastructure of area is estimated is carried out. The estimation of target efficiency of the project comes to the end with the analysis of influence of the given project on realisation of adjacent projects.

Technical validity of the project assumes its estimation on following positions: degrees of a readiness of the design documentation (full, partial); to quality of the feasibility report on the project; to quality (validity level) project concepts; to level of a readiness of technologies offered to use; to quality (validity level) expected building effect; possibilities of reception of additional effects from project realisation.

Economic validity of the project is estimated from the point of view of quality financial and an economic justification of its positions. Should be considered, whether can for the given project to be used joint financing from other sources, and whether adequately own estimation of the applicant reflects project economic benefit. By results of an estimation should be defined, whether needs and whether the project for attraction joint financing from other sources, such as approaches: the federal budget - that is, whether can be considered the project as having federal or inter-regional value; investors - for the projects assuming reception of profit and having considerable building effect; commercial banks for highly profitable projects (irrespective of size of building effect). In a case if in the course of an estimation comes to light that some project applies for high enough profitability, the question is discussed with the applicant, whether support is necessary from the regional budget or financial support can be received from commercial structures. If support of the regional budget is necessary, administration of region and the applicant should choose one of financing forms, for example, granting of a loan or free aid rendering.

The practical realizability of the project is estimated from following positions: realness of the given budget for project realisation; realness of the schedule of realisation of the project; realness of prospective volumes of purchases of technics, the equipment, materials; a professional standard of the project head and its command; level of the social importance of the project (interest of the population in project realisation); realness of creation of cooperation of executors of the project and controllability the project. 


\title{
References
}

1. Matematicheskie osnovy upravlenija proektami: uchebnoe posobie [Mathematical Bases of Management of Projects: Manual]. Moscow, "Higher School" Publ., 2005. 423 p.

2. Barkalov S.A., Babkin V. F. Upravlenie proektami v stroitel'stve: uchebnoe posobie [Management of Projects in Building: Manual]. Voronezh, VGASU Publ., 2000. 310 p.

3. Barkalov S.A., Burkov V.N, Gilyazov N.M. Metody agregirovaniya i upravleniya proektami [Method of Aggregation and Management of Projects]. Moscow, Institute of Control Sciences of Russian Academy of Sciences, 1999. $68 \mathrm{p}$.

4. Burkov V.N, Barkalov S.A. [Model of the Coordination of Interests in a Problem of Management of Projects]. Mathematical Modeling of Information and Technological Systems, 2003, iss. 6, pp. 58-60. (in Russ.)

5. Burkov V.N, Kondrat'yev V.V. Mehanizmy funktsionirovaniya organizatsionnykh sistem [Mehanizmy of Functioning of Organizational Systems]. Moscow, Nauka Publ., 1981. 383 p.

6. Novosel'tsev V. I. Sistemnyi analiz: sovremennye kontseptsii [System Analysis: Modern Concepts]. Voronezh, Quart Publ., 2003. 320 p.

7. Poryadina V.L. Upravlenie sotsial'no-ekonomicheskimi proektami: konkursnyi Podkhod: Monografiya [Management of Social and Economic Processes: Competitive Approach: Monograph]. Voronezh, Publ. and Print. Center "Science Book", 2015. 230 p.

8. Poryadina V.L. [Control Algorithm of Competitive Socio-economic Processes]. Economics and Management Control Systems, 2015, vol. 18, no. 4-4, pp. 490-497.

Received 20 March 2016

Удк 658.1-50

DOI: $10.14529 /$ ctcr160213

\section{МОДЕЛЬ КОНКУРСНОГО УПРАВЛЕНИЯ РЕГИОНАЛЬНЫМИ СТРОИТЕЛЬНЫМИ ПРОЕКТАМИ}

\author{
С.А. Баркалов, В.Л. Порядина
}

Воронежский государственный архитектурно-строительный университет, 2. Воронеж

Описывается вербальная модель, положенная в основу разработки математического обеспечения поддержки принятия решений при конкурсном управлении региональными строительными проектами. Под конкурсным управлением проектами понимается целенаправленный процесс, начинающийся с организации и проведения конкурса, в результате которого проекты-претенденты упорядочиваются на основании определенных критериев, затем победителем (или победителями) объявляется претендент, занявший первое место (или, соответственно, несколько первых мест - в зависимости от условий конкурса), и продолжающийся вплоть до завершения проекта.

Строительные проекты рассматриваются как целостные символьные системы, а управление ими представляется структурной композицией четырех компонентов: субъект, объект управления; окружение проекта; алгоритм управления проектом и критерии качества проекта.

На основе анализа и обобщения опыта управления проектами в строительстве в данной статье разработана вербальная модель конкурсного управления региональными строительными проектами. Предложенная модель расширила и уточнила существующие представления о структуре, порядке организации и механизмах реализации региональных проектов и за счет критериев оценки позволила более адекватно сформулировать задачи, решаемые на стадиях конкурсного управления проектами данного типа.

Ключевые слова: регион, строительство, проект, конкурс, управление, алгоритм. 


\section{Управление в социально-экономических системах}

Лuтература

1. Математические основы управления проектами: учеб. пособие / под ред. В.Н. Буркова. М.: Выстиая школа, 2005. -423 с.

2. Баркалов С.А., Бабкин В.Ф. Управление проектами в строительстве: учеб. пособие / С.А. Баркалов, В.Ф. Бабкин. - Воронеж: Изд-во ВГАСУ, 2000. - 310 с.

3. Баркалов, С.А. Методы агрегирования и управления проектами / С.А. Баркалов, В.Н. Бурков, Н.М. Гилязов. - М.: ИПУ РАН, 1999. - 68 с.

4. Бурков, В.Н. Модель согласования интересов в задаче управления проектами / В.Н. Бурков, C.А. Баркалов // Математическое моделирование информационных и технологических систем. Воронеж: Воронеж. гос. технол. акад., 2003. - Вып. 6. - С. 58-60.

5. Бурков, В.Н. Механизмы функиионирования организационных систем / В.Н. Бурков, В.В. Кондратьев. - М.: Наука, 1981. -383 с.

6. Новосельцев, В.И. Системный анализ: современные концепџии / В.И. Новосельц̧ев. - изд. 2-е, испр. и доп. - Воронеж: Кварта, 2003. - 320 c.

7. Порядина, В.Л. Управление соииально-экономическими проектами: конкурсный подход: моногр. / В.Л. Порядина. - Воронеж: Издат.-полиграф. иентр «Научная книга», 2015. - 230 с.

8. Алгоритм конкурсного управления сочиально-экономическими проектами / В.Л. Порядина // Экономика и менеджмент систем управления. - 2015. - T. 18, № 4-4. - C. 490-497.

Баркалов Сергей Алексеевич, д-р техн. наук, профессор, заведующий кафедрой управления строительством, Воронежский государственный архитектурно-строительный университет, г. Воронеж; sbarkalov@nm.ru.

Порядина Вера Леонидовна, канд. техн. наук, доцент кафедры управления строительством, Воронежский государственный архитектурно-строительный университет, г. Воронеж; poryadina08@mail.ru.

Поступила в редакцию 20 марта 2016 2.

\section{ОБРАЗЕЦ ЦИТИРОВАНИЯ}

Barkalov, S.A. Model of Competitive Management of Regional Building Projects / S.A. Barkalov, V.L. Poryadina // Вестник ЮУрГУ. Серия «Компьютерные технологии, управление, радиоэлектроника». - 2016. - Т. 16, № 2. - C. 131-136. DOI: $10.14529 /$ ctcr160213

\section{FOR CITATION}

Barkalov S.A., Poryadina V.L. Model of Competitive Management of Regional Building Projects. Bulletin of the South Ural State University. Ser. Computer Technologies, Automatic Control, Radio Electronics, 2016, vol. 16, no. 2, pp. 131-136. DOI: 10.14529/ctcr160213 